\title{
Water Quality of Sawaga River, Malaybalay City, Bukidnon, Philippines
}

\author{
Winona Kyle S. Bertomen ${ }^{1}$, Elnor C. Roa $^{2}$, Emilie G. Tubio ${ }^{3}$, Sonnie A. Vedra ${ }^{4}$, Geralyn D. Dela Peña ${ }^{5}$ \\ ${ }^{1}$ Graduate of Bachelor of Science in Environmental Science at Mindanao State University (MSU) - Naawan Campus, Naawan, Misamis \\ Oriental, Philippines \\ ${ }^{2}$ Professor, Chemical Engineer and Doctor of Philosophy in Environmental Chemistry, and a faculty at MSU-Naawan Campus, Naawan, \\ Misamis Oriental, Philippines \\ ${ }^{3}$ Professor, Marine Biologist and Faculty at MSU-Naawan
}

${ }^{4}$ Professor, Doctor of Philosophy in Environmental Science, and Faculty at MSU-Naawan Campus

${ }^{5}$ Research assistant, MSU-Naawan Campus and pursuing Master's Degree in Environmental Science

\begin{abstract}
The study of the water quality of Sawaga River, Malaybalay City was conducted on April 2017. Three sampling stations were established. The river's physico-chemical parameters such as the width, depth, flow rate, temperature, dissolved oxygen (DO), pH, total suspended solids (TSS), nitrate $\left(\mathrm{NO}_{3}-\mathrm{N}\right)$, nitrite $\left(\mathrm{NO}_{2}-\mathrm{N}\right)$, ammonia $\left(\mathrm{NH}_{3}-\mathrm{N}\right)$ and phosphate $\left(\mathrm{PO}_{4}{ }^{3}-\mathrm{P}\right)$ were determined. Results of the study showed that majority of these water quality parameters are within the specified and permissible values set by the Department of Environment and Natural Resources for Drinking Water (Class A) and also passed the water quality criteria for water suitable for fish growth and propagation (Class $C$ ) except for the nitrogen levels in a form of ammonia and nitrite. Nitrogen levels of both forms were detected at appreciably high levels which correspondingly denote pollution. The analyses of the physico-chemical parameters were analyzed parallel with the results of the interviews and respondents' answers of the questionnaire. Holistically, results strongly suggest that Sawaga River is polluted. It is therefore recommended that comprehensive study of its water quality in several other parts of the river and also includes the determination of heavy metals, pesticides, coliform levels will be conducted.
\end{abstract}

Keywords: river, physico-chemical parameters, standards, water quality, sustainable management

\section{Introduction}

Sawaga River is one of the tributaries of Pulangi River. It is located at Malaybalay City, Bukidnon. It stretches 64.5 kilometers connecting from its source, Mount Tuminungan to its end, Pulangi River within the coordinates of $7^{\circ} 58^{\prime} 48.90^{\prime \prime}$ $\mathrm{N}$ and $125^{\circ} 8^{\prime} 49.13^{\prime \prime} \mathrm{E}$. It was one of the major water sources of the city years ago. However, it had previously gone through some natural catastrophes that caused flood and debris that affected some of the barangays in Malaybalay City. On the other hand, there are also infrastructures in the watershed and manmade activities in the river. It has slaughter house, poultries, piggeries and human settlements. Some of the residents near the watershed often do their laundries, take their baths, wash their dishes, throw their garbage, urinate and defecate in the river. The wastes that human activities produced may have affected the quality of the water as well. This study, therefore, was conducted to determine the water quality of Sawaga River located in Malaybalay City, Bukidnon; specifically to measure some of the physico-chemical parameters such as the river's width, depth, flow rate, temperature, Dissolved Oxygen (DO), $\mathrm{pH}$, total suspended solids, Nitrate- $\mathrm{N} \quad\left(\mathrm{NO}_{3}-\mathrm{N}\right)$, Nitrite $-\mathrm{N}$ $\left(\mathrm{NO}_{2}-\mathrm{N}\right)$, Ammonia- $\mathrm{N} \quad\left(\mathrm{NH}_{3}-\mathrm{N}\right)$, and Phosphate-P $\left(\mathrm{PO}_{4}{ }^{3}-\mathrm{P}\right)$ in each of the selected stations. Water quality results define the state of Sawaga River, which will then be a basis for the conservation and management of the river.

\section{Materials and Methods}

\subsection{Study Site}

A total of three sampling stations were established in Sawaga River. The first station was located near the bridge of the diversion road at Barangay Sumpong within the geographical coordinates of $8^{\circ} 9^{\prime} 42.49^{\prime \prime} \mathrm{N}$ and $125^{\circ} 7^{\prime} 3.53^{\prime \prime}$ E. There were human settlements in the area. The second station was located near Bukidnon State University at Fortich Street within the geographical coordinates of $8^{\circ} 9^{\prime} 17.03^{\prime \prime} \mathrm{N}$ and $125^{\circ} 7$ ' 26.62" E. There was an ongoing construction project near the watershed. The third station was located near the City Slaughterhouse at Barangay 9 within the geographical coordinates of $8^{\circ} 8^{\prime} 33.61^{\prime \prime} \mathrm{N}$ and $125^{\circ} 7^{\prime} 46.38^{\prime \prime} \mathrm{E}$. There was less dense vegetation in the area which includes shrubs. A letter addressed to the City Mayor of Malaybalay was sent for permission to conduct this study and was approved. The sampling was done on April 26, 2017 to April 28, 2017 with the guidance of Malaybalay City Government Water Supply System (MCGWSS).

\subsection{Collection and analyses of physic-chemical parameters}

Depth of Sawaga River was determined using a meter stick. It was taken at $50 \mathrm{~cm}$ interval across the river's width. The meter stick was held facing upstream to sufficiently bend it out of the desired position at $90^{\circ}$ to the riverbed. It was immersed in the water until it touches the ground level. The depth was measured for at least 2 to 3 trials from the point of the tip of the meter stick where it touches the ground level to

\section{Volume 6 Issue 7, July 2017}




\section{International Journal of Science and Research (IJSR) \\ ISSN (Online): 2319-7064}

Index Copernicus Value (2015): 78.96 | Impact Factor (2015): 6.391

the point where the meter stick meets the top of the water [1]. Flow rate was determined via float method using a plastic bottle with cap and a timer [2]. This method is considered to be one of the easiest methods to measure surface velocity $\left(\mathrm{v}_{\text {surface }}\right)$ as the ratio of the travel distance to the travel time of the object (Equation 1).

$$
\mathrm{V}_{\text {surface }}(\underline{\mathrm{L}})=\underline{\text { travel distance }}
$$

Since surface velocities are typically higher than the mean velocity, a mean velocity $\left(\mathrm{v}_{\text {mean }}\right)$ is calculated using a correction factor $(k)$ of 0.8 for rough beds and 0.9 for smooth beds (Equation 2). A correction factor of 0.85 is commonly used.

$$
v_{\text {mean }}\left(\frac{\mathrm{L}}{\mathrm{t}}\right)=\mathrm{k} \times \mathrm{v}_{\text {surface }}
$$

The discharge (volumetric flow rate, Q), was calculated by multiplying the cross section area (Across) by the mean velocity (Equations 3 and 4).

$$
\begin{gathered}
A_{\text {cross }}\left(\mathrm{L}^{2}\right)=\text { Width } \times \text { Depth } \\
\left.\mathrm{Q} \frac{\left(\mathrm{L}^{3}\right.}{\mathrm{t}}\right)=\mathrm{A}_{\text {cross }} \times \mathrm{v}_{\text {mean }}
\end{gathered}
$$

Location had the minimum turbulence with the length of at least 3 times the river's width. Direction was parallel to the stream current. The start and end points of the reach were marked wherein the travel time exceeds 20 seconds. The object, particularly the plastic bottle with cap, was dropped into the designated start point of the stream as the timer was simultaneously started. The timer was stopped as the object reaches its end point. The process was repeated to obtain 3 trials. Width was determined by using Bushnell Tour V2 Slope Edition Rangefinder. Temperature and DO was determined by using HOBO U26-001 Dissolved Oxygen Logger. $\mathrm{pH}$ was determined by using EZODO GOnDO PH5011 pH Meter.

Water samples were collected from the selected stations of Sawaga River. There were 3 replicates of water samples in every station and each sample was placed and properly labeled in a $350 \mathrm{~mL}$ plastic bottle. These samples were then brought to MSU-Naawan Research Chemistry Laboratory for nutrient analyses particularly total suspended solids, Nitrate- $\mathrm{N} \quad\left(\mathrm{NO}_{3}-\mathrm{N}\right)$, Nitrite- $\mathrm{N} \quad\left(\mathrm{NO}_{2}-\mathrm{N}\right)$, Ammonia-N $\left(\mathrm{NH}_{3}-\mathrm{N}\right)$ and Phosphate- $\mathrm{P}\left(\mathrm{PO}_{4}{ }^{3}-\mathrm{P}\right)$.

\subsection{Collection and analyses of social factors}

The social aspect of this study focused on the attitude, knowledge and perception of the residents near Sawaga River regarding its present condition. Respondents were either a male or a female residing near Sawaga River and were 18 years old and above. The questionnaire was written in common vernacular for the respondents' easy comprehension Sample size for this study was determined through the Creative Research Systems' online Sample Size Calculator using the formula below:

$$
\mathrm{ss}=\frac{\mathrm{Z} 2 *(\mathrm{p}) *(1-\mathrm{p})}{\mathrm{C}^{2}}
$$

Where ss = sample size; $Z=Z$ value (e.g. 1.96 for $95 \%$ confidence level); $\mathrm{p}=$ percentage picking a choice, expressed as decimal (0.5 used for sample size needed); and $\mathrm{c}=$ confidence interval, expressed as decimal (e.g. $0.04= \pm 4$ )
[3]. Results were presented using descriptive statistics particularly using the percentage and mean.

\subsection{Statistical analyses}

One Way Analysis of Variance (ANOVA) with Tukey's HSD Multiple Comparison Test was used in this study to determine the significant difference on data for both physicochemical parameters and social variables. The result was also compared to the Water Quality Guidelines and General Effluent Standards of 2016 according to the DENR Administrative Order No. 2016-08 [4] to determine the classification of Sawaga River.

\section{Results and Discussions}

The results of the analyses of the different chemical parameters as well as the physical characteristics of Sawaga River are shown in Table 1.

Table 1: Results of the physico-chemical parameters obtained from the three sampling stations

\begin{tabular}{lccc}
\hline Parameters & Station 1 & Station 2 & Station 3 \\
\hline Width $(\mathrm{m})$ & 29 & 19 & 23 \\
Depth $(\mathrm{m})$ & 22.66 & 38.66 & 49 \\
Stream flow $\left(\mathrm{m}^{3} / \mathrm{s}\right)$ & 3.18 & 5.26 & 4.96 \\
Temperature $\left({ }^{\circ} \mathrm{C}\right)$ & $24.83^{\mathrm{a}}$ & $26.83^{\mathrm{a}}$ & $30.66^{\mathrm{b}}$ \\
$\mathrm{DO}(\mathrm{mgO} / \mathrm{L})$ & $7.68^{\mathrm{b}}$ & $7.29^{\mathrm{b}}$ & $6.63^{\mathrm{a}}$ \\
$\mathrm{pH}$ & $7.73^{\mathrm{a}}$ & $7.63^{\mathrm{a}}$ & $7.80^{\mathrm{a}}$ \\
$\mathrm{TSS}(\mathrm{mg} / \mathrm{L})$ & 0.042 & 0.055 & 0.034 \\
$\mathrm{NO}_{3}-\mathrm{N}(\mathrm{ppm})$ & $1.365^{\mathrm{a}}$ & $1.463^{\mathrm{a}}$ & $1.897^{\mathrm{b}}$ \\
$\mathrm{NO}_{2}-\mathrm{N}(\mathrm{ppm})$ & $0.123^{\mathrm{a}}$ & $0.145^{\mathrm{b}}$ & $0.150^{\mathrm{c}}$ \\
$\mathrm{NH}_{3}-\mathrm{N}(\mathrm{ppm})$ & $0.590^{\mathrm{b}}$ & $0.347^{\mathrm{a}}$ & $0.591^{\mathrm{b}}$ \\
$\mathrm{PO}_{4}{ }^{3} \mathrm{P}(\mathrm{ppm})$ & $0.097^{\mathrm{a}}$ & $0.122^{\mathrm{b}}$ & $0.117^{\mathrm{b}}$ \\
\hline
\end{tabular}

Legend: superscripts of the same letter in the row means not significant at $\alpha \geq 0.05$

\subsection{Stream flow rate}

Stream flow rate is an important thing to consider in terms of analyzing water quality. It affects everything from the temperature and concentration of various substances in the water to the distribution of habitats and organisms throughout the particular water body [5].

The stream flow rate of Sawaga River ranged from $3.18 \mathrm{~m}^{3} / \mathrm{s}$ to $5.26 \mathrm{~m}^{3} / \mathrm{s}$ (Table 1). The difference of flow rate between the three stations may be due to the river's geographical landforms. There were rocks along the Station 1 of the river and the landform was slightly plain. On the other hand, the area of the Station 2 was observed to be wider and deeper compared to other stations which may have also affected the flow rate. Another factor that may have caused the increase of flow rate is the water discharge from its upstream because as the water discharge increases, the stream velocity also increases which may then affect the cross sectional shape of the river [6]. The obvious change in volumetric flow is an indication of possible diversion of water from the river for irrigation, thus, lower stream flow or a convergence of a tributary to Sawaga River that may then increase the stream flow. The quantity of water that could be generated by

\section{Volume 6 Issue 7, July 2017 www.ijsr.net}




\section{International Journal of Science and Research (IJSR) \\ ISSN (Online): 2319-7064}

Index Copernicus Value (2015): 78.96 | Impact Factor (2015): 6.391

Sawaga River in a month can be estimated using the stream flow rate obtained in this study. The calculated estimated volume of water that Sawaga can possibly supply based on the stream flow rate of $4.96 \mathrm{~m}^{3} / \mathrm{sec}$ corresponds to approximately $12,856,320 \mathrm{~m}^{3}$. If all of the water present in Sawaga River will be used, then all households are assured of water supply but this cannot be done or else the river will suffer to its consequence.

\subsection{Water temperature}

Water temperature should be considered when determining metabolic rates and photosynthesis production, compound toxicity, dissolved oxygen and other dissolved gas concentrations, conductivity and salinity, oxidation reduction potential (ORP) and $\mathrm{pH}$. It is defined as an "abiotic master factor" since it nearly affects every other water quality parameter [7].

The water temperature readings of Sawaga River ranged from $24.83^{\circ} \mathrm{C}$ to $30.66^{\circ} \mathrm{C}$. The highest temperature reading observed in Station $3\left(30.66^{\circ} \mathrm{C}\right)$ differed significantly from the temperature readings observed in Station $1\left(24.83^{\circ} \mathrm{C}\right)$ and Station $2\left(26.83^{\circ} \mathrm{C}\right)$. The significant temperature difference among stations could be attributed to the time when sampling was done. The collection of water samples in Stations 1, 2 and 3 was done at 9:00, 9:28 and 10:05 in the morning, respectively. It may also be acquired due to soil erosion and increased turbidity caused by the rain on the evening before the day of sampling. The factors that could cause these differences are air temperature, amount of shade, soil erosion increasing turbidity and thermal pollution from human activities [7].

\subsection{Dissolved oxygen}

Dissolved oxygen is essential to the aquatic life. It can get into the water through the mixing of atmospheric oxygen or during the process of photosynthesis. Changes in oxygen concentration may affect species that are dependent on oxygen-rich water [8].

The dissolved oxygen of Sawaga River ranged from 6.63 $\mathrm{mgO} / \mathrm{L}$ to $7.76 \mathrm{mgO} / \mathrm{L}$. Statistical analysis revealed that DO levels in Stations 1 and 2 are significantly higher than in Station 3. It was observed that Station 3 had the lowest amount of dissolved oxygen $(6.63 \mathrm{mgO} / \mathrm{L})$

Like any other water parameters, dissolved oxygen is also influenced by some factors including natural and manmade. The DO level at Station 3 is significantly lower than that of the other stations may be because of the presence of decomposing materials from the upper part of the river particularly the domestic and agricultural effluents. Observable decreasing trend of DO levels is also obvious. Opposing pattern of temperature with dissolved oxygen was also observed, thus, areas with high temperature are expected to exhibit low dissolved oxygen. Accordingly, water with high temperature cannot hold more dissolved oxygen compared to that of lower temperature [8]. In addition, the DO levels in the three stations of Sawaga River are comparable to the DO levels in the lower stations (5.75 to $5.87 \mathrm{mgO} / \mathrm{L}$ ) of Layawan River [9]. However, the DO levels of both rivers are more than the minimum $5.0 \mathrm{mgO} / \mathrm{L} \mathrm{DO}$ requirement for Class $\mathrm{A}$ and $\mathrm{C}$ waters [4] or water used for drinking purposes and water suitable for fish growth and propagation, respectively.

\subsection{Water pH}

$\mathrm{pH}$ is a numeric scale used to specify the acidity or alkalinity of an aqueous solution. The $\mathrm{pH}$ value of a neutral solution is 7. Thus, the solution that has a $\mathrm{pH}$ value within the range of 0 to 7 is considered as acidic and a $\mathrm{pH}$ value within the range of 7 to 14 is considered basic [10].

The $\mathrm{pH}$ readings in all stations are within the $\mathrm{pH}$ range normal to river waters (6.5 to 9.0 ). Understandably why there are no significant differences of $\mathrm{pH}$ readings among study stations. It must be noted that in this study, the DENR guidelines for freshwater [4] suitable for fish propagation (6.5 to 9.0) and for water suitable for drinking (6.5 to 8.5) are both satisfied.

\subsection{Total suspended solids and sediment load}

Total suspended solid is one of the most visible indicators of water quality. High levels of TSS increase water temperature and decrease dissolved oxygen levels since suspended particles absorb more heat from solar radiation than water molecules do [11].

Soil erosion, urban runoff, wastewater and septic system effluent and decaying plants and animals are some of the factors that can affect its level [12]. The TSS level in Station 2 is higher compared to the other stations. This elevated TSS concentrations may be due to the disturbance of the land surface since Station 2 is located near the ongoing construction site and may also be due to the rain that occurred the night before the sampling was done. Also, the organic and inorganic suspended particles contributed by the anthropogenic activities of the residential areas and livestock (e.g. poultries and piggeries) from some parts of the river are usually carried by its current and pass through this station. In addition, the TSS levels in the three stations of Sawaga River are comparable to the TSS levels in the lower stations (3.43 to $4.66 \mathrm{mg} / \mathrm{L}$ ) of Layawan River [9]. However, the TSS levels of both rivers fell below the maximum permissible TSS levels for Class A (50 mg/L) and Class C (80 mg/L freshwater systems [4].

\subsection{Nitrate $-\mathrm{N}\left(\mathrm{NO}_{3}-\mathrm{N}\right)$}

Nitrate is the most common form of inorganic nitrogen even in unpolluted waters [8]. Nitrates found in water bodies may occur naturally from the earth but excess levels of nitrates can imbalance ecosystems [13] and can be considered to be a contaminant of ground and surface waters. The source of excess nitrates can usually be traced to agricultural activities or human wastes from fertilizers or manures [14].

The significant differences in the nitrate $-\mathrm{N}$ concentration in Station 3 to Stations 1 and 2 could be attributed to agricultural runoff, over fertilized croplands, decomposing materials from farms, livestock wastes, poultries located upstream. In addition, bodies of dead animals thrown into the

\section{Volume 6 Issue 7, July 2017 www.ijsr.net}




\section{International Journal of Science and Research (IJSR) \\ ISSN (Online): 2319-7064}

Index Copernicus Value (2015): 78.96 | Impact Factor (2015): 6.391

river were seen in the station when sampling was conducted. This is in one way or another must have contributed to the elevated nitrate concentration in Station 3. However, it is good to note that the Nitrate- $\mathrm{N}$ levels observed in all stations do not exceed the maximum permissible nitrate- $\mathrm{N}$ concentration of $7.0 \mathrm{ppm}$ for both Class $\mathrm{A}$ and $\mathrm{C}$ water or water suitable for drinking and water suitable for growth and propagation of fish, respectively [4].

\subsection{Nitrite- $\mathrm{N}\left(\mathrm{NO}_{2}-\mathrm{N}\right)$}

Nitrite is not usually found at measurable levels since it is converted from ammonia and to nitrate again very rapidly. Nitrite concentration of a waterbody that exceeds from 0.2 ppm is considered polluted [8].

The significant differences in nitrite- $\mathrm{N}$ concentration among stations could be attributed to the pollutants from the upstream that may have settled in both Station 2 and 3 . Although the three stations exhibited significantly varying nitrite $-\mathrm{N}$ concentrations but it must be noted that none of these stations exceeded the $0.2 \mathrm{ppm}$ nitrite $-\mathrm{N}$ concentration for water that could be considered a polluted one. The farther the pollutants flow along the river, the more pollutants are being collected and gathered to where they settle all due to gravity and the natural flow of the river and these pollutants may be caused by manmade activities [15]. These particular pollutants that affected the nitrite $-\mathrm{N}$ concentration could be the same pollutants that affect the other nutrients such as decaying materials, manures and fertilizers brought by agricultural runoff. The declaration of the residents in the vicinity as well as the answer of the people residing nearby during the interview suggests that agricultural activities are present in the upstream area.

\subsection{Ammonia-N $\left(\mathrm{NH}_{3}-\mathrm{N}\right)$}

Ammonia should also be considered in terms of water quality sampling for it affects the other nutrient concentration and dissolved oxygen. It can lower its level and can also be toxic when excessive but can also limit plant growth when too low [16].

The relatively high levels of ammonia- $\mathrm{N}$ detected in all stations could be attributed to decaying plants and animals, and animal waste. Ocular observations during sampling revealed that these types of wastes are present in the area. The range of ammonia $-\mathrm{N}$ concentration (0.347 to 0.591 ppm) observed in all stations exceeded the maximum permissible 0.05 ppm ammonia-N specified in the DAO No. 2016-08 [4] for Class A and C waters.

\subsection{Phosphate- $\mathrm{P}\left(\mathrm{PO}_{4}{ }^{3}-\mathrm{P}\right)$}

Phosphate as a compound, which contains phosphorous, is often the nutrient that limits how much plant growth occurs in a water body. Phosphate concentrations can be quite high due to higher concentrations of sediment that wash into the stream during stormy days [8].

The detection of phosphate-P in water from all stations may have been due to excess nutrients from fertilizers brought by anthropogenic activities like agricultural farming which are seen present in the river banks and the consequence of using the river for bathing and laundry, thus, the residue from detergents and soaps which are good sources of phosphorous. The detected range of phosphate- $\mathrm{P}$ concentrations, however, is some folds lower than the permissible phosphate- $\mathrm{P}$ concentration of $0.5 \mathrm{ppm}$ for both Class $\mathrm{A}$ and Class $\mathrm{C}$ water [4].

\subsection{Social factors}

The socio-demographic characteristics of the respondents must be considered in order to know whether the source of the knowledge, perception and attitude towards Sawaga River is reliable enough.

The knowledge, perception and attitude of the respondents regarding Sawaga River must also be considered in order to describe their behavior towards the river, to hear their opinion and to know and recommend appropriate policy measures for the sustainable conservation and management of Sawaga River which could also benefit the community.

The livelihood of the respondents does not really depend on the river. Majority of them get water from the Malaybalay City Water District (MCWD) wherein $70 \%$ of the water was taken from Kibalabag River treated by the Malaybalay City Government Water Supply System (MCGWSS), while 10\% to $30 \%$ of the water was taken from Sawaga River treated by MCWD. There were some respondents who still throw garbage in Sawaga River especially when there were times that the City Garbage Collection were not able to collect their garbage in every household in the residential area near the river. Most of them are aware how valuable Sawaga River is since it provides habitat not only for flora and fauna but also for the human race. The result showed that the river is important for the community because it is useful for bathing and doing laundry. It also serves as a source of water and food for some residents. There were also currently existing programs regarding the conservation of Sawaga River such as clean-up drive and tree planting in the riparian areas. There are also activities and infrastructures near the river and these are throwing of garbage, bath and laundry, electric fishing, human settlements, poultry/livestock and slaughterhouse. As observed by the respondents, these activities and infrastructures affected the river by slowly degrading it. The area became more congested and will be prone to natural calamities such as flood and that humans may acquire diseases from it due to degradation of the river. Most respondents think that the community should do something about it because they think that it would also affect its water quality. The respondents suggested that it would be better to implement the programs strictly and encourage the people to dispose and segregate waste properly, discipline the people and stop electric fishing.

\section{Conclusion and Recommendations}

The physico-chemical parameters of Sawaga River in Malaybalay City were determined in order to present the water quality condition of the resource. The results of this study revealed that the physico-chemical parameters considered in the study like water temperature, $\mathrm{pH}$, TSS, DO, nitrate-N, phosphate-P had values that satisfied the

\section{Volume 6 Issue 7, July 2017 www.ijsr.net}




\section{International Journal of Science and Research (IJSR) \\ ISSN (Online): 2319-7064}

Index Copernicus Value (2015): 78.96 | Impact Factor (2015): 6.391

requirements for Class A water or water suitable for public water supply class II - Intended as sources of water supply requiring conventional treatment (coagulation, sedimentation, filtration and disinfection) to meet the latest Philippine National Standards for Drinking Water). Likewise, the same parameters had values that also satisfied the requirements for Class $\mathrm{C}$ water or Fishery water for the propagation and growth of fish and other aquatic resources except for ammonia that exceeded the maximum ammonia concentration for both types of water. Exceedance of ammonia is an indication of pollution from both organic and inorganic sources. Ocular observations can attest to these findings where domestic wastes are rampant and garbage disposal were visible. Likewise, nitrite is also at detectable values that can also support the suspicion of water pollution. Based on the information gathered from the interview, most of the respondents were aware about the state of Sawaga River. Some think that it is too late to take action but most of the respondents are hopeful that the river can still be conserved. Majority believed that the degeneration of the river was mainly caused by the anthropogenic activities done by humans such as laundry, bathing, electric fishing and throwing of garbage as well as infrastructures such as housing, poultries and piggeries that make the area congested and prone to natural calamities. However, there are community programs implemented for the conservation of Sawaga River such as tree planting and clean-up drive.

Based on personal interview, the MCWD acquire $10 \%$ to $30 \%$ of their drinking water from Sawaga River and the most from Kibalabag River. The estimated quantity of water that could be generated by Sawaga River in a month is approximately $12,856,320 \mathrm{~m} 3$ which is a good quantity of water that can supply ample number of households.

Generally, the water quality of Sawaga River is relatively good as most of its values are within the minimum requirements for water classified as Class A and Class C. However, results of interview and answers of the questionnaires strongly suggest that Sawaga River is already polluted where in this study the high level of ammonia and the detection of nitrite can support to this claim.

Based on the results of the study, the following are recommended:

1) The existing programs for the conservation of Sawaga River must be sustained and properly implemented.

2) The people in the community must be disciplined and educated in terms of proper waste segregation and disposal. Thus, IEC (Information and Education Campaign Program) must be strengthened.

3) A comprehensive water quality study in Sawaga River is highly recommended. Water quality parameters like total coliform and $e-$ coli, heavy metals like cadmium and lead, pesticides including organo-chlorine and organophosphates are recommended parameters to be included in the assessment.

\section{Acknowledgment}

The authors thank the Malaybalay City Government Water Supply System (MCGWSS) especially Mr. Tomas Taga and Mr. Florante Bergado, Local government units of Malaybalay Bukidnon, Ms. Rachel Apales, Prof. Rey L. Roa, Mr. Dave P.
Supat, Mr. Raymond A. Levine, Mrs. Christine S. Levine, Ms. Amy J. Laurden and Mindanao State University at Naawan for the supports and assistance during the conduct of the study.

\section{References}

[1] Geography Site, "River Cross Sections. Geography Site", available at http://www.geography-site.co.uk, Feb. 20, 2016.

[2] T.J. Buchanan, and W.P. Somers, "Techniques of WaterResources Investigations of the United States Geological Survey: Discharge Measurements at Gagging Stations", Washington, DC: United States Government Printing Office. 1969.

[3] Creative Research Systems, "Survey Research Aids: Sample Size Calculator, available at https://www.surveysystem.com/sscalc, 2012.

[4] DENR Administrative Order, "Water Quality Guidelines and General Effluent Resources of 2016", Department of Environment and Natural Resources, May 24, 2016.

[5] Water on the Web, "Stream Flow", National Science Foundation, available at http://www.waterontheweb.org/under/waterquality/flow, Jan. 172008

[6] S.A. Nelson, "Natural Disasters: River Systems and Causes of Flooding", New Orleans: Tulane University, pp. 1-13, EENS 3050, available at http://www.tulane.edu/ sanelson/Natural_Disasters/river systems, Oct. 18, 2016

[7] Fondriest Environmental, Inc., "Water Temperature", Fundamentals of Environmental Measurements, available at http://www.fondriest.com/environmentalmeasurements, 2014.

[8] N. Mesner and J. Geiger, "Understanding Your Watershed: Phosphorous", Utah State University, Water Quality Extension, available at http://extension.usu.edu/waterquality, December 2010

[9] E. Roa, C. Hansel, S. Nacua, R. Seronay, M. Gorospe, A. Villarino, T. Poblete, F.F. Freire, K. Culminas, D. C. Bacaltos, A. Mohagan, B. Roscom, and W. H. Gay, "Assessing the Headwaters of Layawan River: Linkage between the Terrestrial and Aquatic Ecosystems in Mt. Malindang, Misamis Occidental”, Laguna: Biodiversity Research Programme for Development in Mindanao: Focus on Mt. Malindang and Environs. SEAMEO SEARCA, College, Laguna, 2006.

[10] S.K. Lower, "Acid - Base Equilibria and Calculations", Simon Frayer University, A Chem, 2014.

[11]E. Mousavi, "Turbidity, Total Suspended Solids and Water Clarity”, University of Tasmania, 2016.

[12] S. Murphy, "General Information on Solids. Boulder City” USGS Water Quality Monitoring, 2007.

[13]P. Berardelli, "Nitrate Threatening the Nation's Watersheds", American Association for the Advancement of Science, 2008.

[14] Partnership for Environmental Education and Rural Health, "Nitrate and Their Effect on Water Quality - A Quick Study", Wheatley River Improvement Group. 2010

[15]H. Perlman, "Rivers", USGS Science for a Changing World, 2015.

[16]Lehigh Environmental Initiative”, Ammonium

\section{Volume 6 Issue 7, July 2017 www.ijsr.net}




\section{International Journal of Science and Research (IJSR) \\ ISSN (Online): 2319-7064}

Index Copernicus Value (2015): 78.96 | Impact Factor (2015): 6.391

Nitrogen”, LEO Enviro Sci Inquiry, 2000.

\section{Author Profile}

Winona Kyle S. Bertomen is a graduate of Bachelor of Science in Environmental Science at Mindanao State University (MSU) -

Naawan Campus, Naawan, Misamis Oriental, Philippines. winonakyle@ymail.com

Prof. Elnor C. Roa is a Chemical Engineer and Doctor of Philosophy in Environmental Chemistry, and a faculty at MSUNaawan Campus, Naawan, Misamis Oriental, Philippines. E-mail: elnorcroa@gmail.com

Prof. Emilie G. Tubio is a marine biologist and a faculty at MSUNaawan. E-mail: emiliegtubio@gmail.com

Prof. Sonnie A. Vedra is a Doctor of Philosophy in Environmental Science, and a faculty at MSU-Naawan Campus.

Geralyn D. dela Peña is a research assistant at MSU-Naawan Campus and currently pursuing Master's Degree in Environmental Science

Volume 6 Issue 7, July 2017 www.ijsr.net 